\title{
ARTICLES
}

Submitted 04-29-2020. Approved 06-16-2021

Evaluated through a double-blind review. Guest Scientific Editor: Sanderson Macedo Barbalho

Translated version | DOI: http://dx.doi.org/10.1590/S0034-759020220303x

\section{ADOPTION AND DIFFUSION OF TECHNOLOGIES 4.0 BASED ON THE INNOVATIVE TRAJECTORY AND THE SCALE OF OPERATION: THE CASE OF CHILE}

\author{
Adopción y difusión de las tecnologias 4.0 a partir de la trayectoria \\ innovativa y la escala de operación: El caso de Chile
}

\author{
Adoção e difusão de tecnologias 4.0 baseadas na trajetória inovadora e na \\ escala de operação: O Caso do Chile
}

Francisco Gatica-Neira ${ }^{1}$ | fģatica@ubiobio.cl | ORCID: 0000-0002-1968-9384

${ }^{1}$ Universidad del Bío-Bío, Departamento de Economia y Finanzas, Facultad de Ciencias Empresariales, Concepción, Chile

\begin{abstract}
The factors that can explain the diffusion of 4.0 technologies in the chilean economy are analyzed. We work with companies that can be classified as "specialized suppliers" and "science-based" relevant to the analyzed technological field. The data from the Tenth National Innovation Survey carried out by the National Statistics Institute (INE, 2018) are used. A confirmatory factor analysis of the second order is performed to identify the variables that best explain the diffusion. Lisrel 8.8 software was used, making the estimations with the robust diagonal weighted least squares method (DWLS) because we work with ordinal variables. The main results show the relevance of future innovation projects and the number of workers hired by each company to stimulate technological diffusion.
\end{abstract}

Keywords: Technological diffusion processes, government policies, confirmatory factor analysis, industry 4.0 , technological innovation.

\section{RESUMEN}

Se analizan los factores que pueden explicar la difusión de las tecnologías 4.0 en la economía chilena. Trabajamos con las empresas que pueden ser calificadas como "proveedoras especializadas" $y$ "basadas en ciencias" pertinentes al campo tecnológico analizado. Se utilizan los datos de la Décima Encuesta Nacional de Innovación realizada por el Instituto Nacional de Estadística (2018). Se realiza un análisis factorial confirmatorio de segundo orden para identificar las variables que mejor explican la difusión. Se utilizó el software Lisrel 8.8 realizando las estimaciones con el método de mínimos cuadrados ponderados diagonales robustos (DWLS) debido a que se trabaja con variables ordinales. Los principales resultados dan cuenta de lo relevante de los proyectos de innovación futura y la cantidad de trabajadores contratados por cada empresa para estimular la difusión tecnológica.

Palabras Clave: Procesos de difusión tecnológica, políticas gubernamentales, análisis factorial confirmatorio, industria 4.0, innovación tecnológica.

\section{RESUMO}

São analisados os fatores que podem explicar a difusão de tecnologias 4.0 na economia chilena. Trabalhamos com empresas que podem ser classificadas como "fornecedores especializados" e "baseados na ciência" relevantes para o campo tecnológico analisado. São utilizados os dados da Décima Pesquisa Nacional de Inovação, realizada pelo Instituto Nacional de Estatística (2018). Uma análise fatorial confirmatória de segunda ordem é realizada para identificar as variáveis que melhor explicam a difusão. Utilizou-se o software Lisrel 8.8, realizando as estimativas com o método robusto de mínimos quadrados ponderados na diagonal (DWLS) devido ao trabalho com variáveis ordinais. Os principais resultados mostram a relevância de futuros projetos de inovação e o número de trabalhadores contratados por cada empresa para estimular a difusão tecnológica.

Palavras-Chave: Processos tecnológicos de difusão, políticas governamentais, análise fatorial confirmatória, indústria 4.0, inovação tecnológica. 


\section{INTRODUCTION}

This article analyzes factors that can explain the diffusion of technologies 4.0. These technologies encompass the application of sensors, learning algorithms, process virtualization, the Internet of Things (IoT), and other developments that improve the profitability and flexibility of production processes.

The study explores the diffusion power of sectors linked to Industry 4.0 in the categories of specialized suppliers and science-based companies. A second-order confirmatory factor analysis was conducted, in line with the structural equation models, adopting ordinal variables and using robust diagonal weighted least squares (DWLS) as an estimation method. The research database consists of 313 Chilean companies, listed in the Tenth National Innovation Survey conducted by the Chilean National Statics Institute (2018).

The topic search conducted in April 2021 in the Web of Science core collection using first the term "Industry 4.0" and then "Chile" showed 11 studies. The themes addressed were the use of applications in the copper industry, forestry, aquaculture, environmental issues (CO2), nutrition, and manufacturing. This search did not find studies in Chile investigating factors connected with the adoption and diffusion of technologies 4.0 considering a global perspective and using structural equation models. The articles found focused on identifying barriers to the adoption of technologies in specific sectors. Therefore, to the best of my knowledge, this study fills a research gap by offering a model based on data that explains the determinants of the adoption and use of technologies 4.0.

One of the main conclusions is that the diffusion of technologies can be explained mainly by innovation rather than by the company's operation scale. The crucial variables that supported this finding were the possibility of future innovation, the capacity to innovate based on challenges perceived, the percentage of qualified employees, and the total number of employees.

\section{EMERGENCE OF TECHNOLOGIES 4.0}

Through digitizing different connections, the Fourth Industrial Revolution completely changes the configuration of value chains (Schwab, 2016; Tirole, 2017). The technologies 4.0 cross all sectors of the economy and allow for an improvement in modularity, service orientation, decision-making capacity, decentralization, virtualization, and interoperability of processes (Lasi, Fettke, Feld, Kemper \& Hoffmann, 2014; Hermann, Pentek, \& Otto, 2016; Lee, Bagheri, \& Kao, 2015).

This technological revolution has strongly impacted employment, especially in developing countries (Nedelkoska \& Quintini, 2018). Prospective studies in Western Europe (Berger, 2016) present a curve where the unemployment rate rises and, after 20 years, employment recovers and returns to the levels before the automation process. The speed of job recovery results in new companies from the relocation of new businesses, the emergence of the technological equipment industry, and the development of services based on technologies 4.0 (Berger, 2016). 
In this context, Bogliacino and Pianta (2016) analyze Pavitt's taxonomies based on the review of innovation data from manufacturing and service companies in the European Union, verifying the heterogeneity of innovation models at the sectoral level. One conclusion is that public policies must focus on the categories of specialized suppliers and science-based companies, maximizing the diffusion of the technologies 4.0 emerging from these organizations to companies operating in other sectors of the economy. This diffusion may also occur via the implementation of collaboration opportunities between clients and suppliers or by connecting research centers (Lepore, Dubbini, \& Micozzi, 2021).

This research studied the factors that explain the adoption and diffusion of technologies 4.0 in specialized suppliers and science-based companies (see Exhibit 1), which are fundamental to expand the benefits of Industry 4.0 to all companies of the Chilean economy.

Exhibit 1. Identification of the economic sectors

\begin{tabular}{c|l}
\hline $\begin{array}{c}\text { Identification of } \\
\text { economic activity }\end{array}$ & Description of the economic activity for the sectors "science-based" and "specialized suppliers" \\
\hline 26 & Manufacture of computers, electronic, and optical products. \\
\hline 27 & Manufacture of electrical equipment \\
\hline 28 & Manufacture of machinery and equipment \\
\hline 61 & Telecommunications \\
\hline 72 & Scientific research and development. \\
\hline
\end{tabular}

Source: Elaborated by the authors based on the Décima Encuesta Nacional de Innovación (2018).

In the Chilean case, technologies 4.0 are in an early stage of diffusion. The Ministry of Economy (Minecon, 2020) recently published a survey applied to 3,344 companies about the level of information and communication technologies (ICT) adoption, with emphasis on big data and radio frequency identification (RFID). Two conclusions stand out:

- There is a significant gap in the diffusion of these complex technologies concerning the average numbers of Organisation for Economic Co-operation and Development (OECD) countries. For example, 2\% of Chilean companies use big data against 13\% of companies in other OECD countries. As for RFID, 6\% of Chilean companies use the technology, against 14\% of businesses in OECD companies.

- There is a gap in the level of technology adoption according to the company size. For example, $7.2 \%$ of large companies use big data, while only $1.7 \%$ of small and mediumsized companies have adopted this technology. RFID is used in $22 \%$ of large companies and only in $4 \%$ of small and medium-sized companies.

In this scenario, public policies are essential to technologies 4.0 diffusion nationwide, reaching more small and medium companies. Currently, there is no public policy in Chile to develop and disseminate technologies 4.0 in different economic sectors. Instead, the focus is 
on developing technologies 4.0 to apply sensors and monitor the mining sector and the natural resource-intensive industry (Gatica \& Ramos, 2020).

It is essential to have an industrial policy that stimulates the adoption of technologies 4.0 and helps incorporate new management practices oriented to learning and developing the capacity for innovation, offering infrastructure, human capital, and strategic partnerships (Lepore et al., 2021). In this sense, public policy can:

- Solve technological infrastructure problems, build legal frameworks, and provide information security (Chauhan, Singh, \& Luthra, 2021).

- Play a strategic role in facilitating innovation initiatives for this type of technology in small companies (Chege, Wang, \& Suntu, 2020).

- Stimulate the creation of new business models as a way to generate jobs to boost economic development (Dean \& Spoehr, 2018), and

- $\quad$ Promote the opening of markets with greater technological content, facilitating company emergence (Mazzucato, 2017).

This study provides information to stimulate the diffusion of these new technologies in the Chilean industry, filling a gap in the current literature.

\section{LITERATURE REVIEW}

This section presents a literature review to justify the different hypotheses of the structural equations model (Exhibit 2).

Companies with an innovative track record have greater organizational flexibility, a fundamental condition for adopting and disseminating technologies 4.0. Therefore, a business culture willing to innovate, together with a continuous improvement strategy of processes and products, facilitates the adoption of new technologies (Agostini \& Filippini, 2019; Horváth \& Szabo, 2019; Rojas-Córdova, Heredia-Rojas, B., \& Ramírez-Correa, 2020). This promotes the generation of new business models through personalizing consumption, commercializing new algorithms that complement the production, and through more effectively operating a value network (Botha, 2019; Müller, Kiel, \& Voigt, 2018).

The incorporation of technologies 4.0 demands significant financial, technological, and human resources (Arnold, Veile, \& Voigt, 2018; Dalenogarea, Benitez, \& Ayala, 2018; Ingaldi \& Ulewicz, 2020). The leader must manage the uncertainty involved in all technical changes, breaking organizational inertias and fears (Chauhan et al., 2021). Given the scarcity of resources and high costs, companies must define feasible objectives to generate a successful digital transformation process (Kiraz, Canpolat, Özkurt, \& Taşkın, 2020).

Companies with an innovative trajectory - i.e., those that innovated in the past, intend to engage in innovative projects in the future, and face fewer challenges to develop innovation have a greater capacity to adopt and disseminate new technologies 4.0. Three hypotheses arise: 
$\mathrm{Hl}$ : There is a positive relationship between the past innovation rate and innovative capacity, increasing the technologies 4.0 diffusion power.

H2: There is a positive relationship between plans for future innovation projects and innovative capacity, which favors technologies 4.0 diffusion power.

H3: There is a positive relationship between the capacity to innovate based on perceived challenges and innovative capacity, increasing the technologies 4.0 diffusion power.

Analyses of the adoption processes of specific technologies - RFID, big data, B2B - show that qualified human capital is essential, allowing to explore, adapt, and integrate new technologies (Chege et al., 2019; Reyes \& Visich, 2016; Vowles, Thirkell, \& Sinha, 2011). Companies that have human resources with digital and innovative skills are more likely to adopt technologies 4.0, reducing resistance to the changes involved in this process (Agostini \& Filippini, 2019; CabreraSánchez \& Villarejo-Ramos, 2019).

Qualified employees recognize the benefits of investing in technologies 4.0, which suggests that such technologies are more likely to be adopted in companies with this profile of employees (Prause \& Günther, 2019; Reyes et al., 2016). The advantages of technologies 4.0 may be expanded as more qualified employees tend to make better use of them and gain efficiency (Fuente, Rojas, \& Leiva, 2020). Thus, companies with qualified employees may be better positioned to visualize new markets and clients, which is key in deciding whether to start a digital transformation process (Kiraz et al., 2020).

Thus, companies must have skilled employees to search, recognize benefits, and implement new technologies, which leads to another three hypotheses:

H4: There is a positive relationship between the percentage of employees who hold a graduate degree and the company's innovative capacity, which favors the technologies 4.0 diffusion power.

H5: There is a positive relationship between the percentage of qualified employees and innovative capacity, which facilitates the technologies 4.0 diffusion power.

H6: There is a positive relationship between the sales variation and the innovative capacity, which contributes to the technologies 4.0 diffusion power.

Finally, the decision to invest in ICT depends on the company's size due to the high financial barriers involved (Brambilla, 2018). Large companies, especially multinationals, have fewer barriers to adopting technologies 4.0 (Horváth \& Szabo, 2019). Ingaldi and Ulewicz (2020) identify that having obsolete technology makes adoption difficult, a situation more frequently observed in older companies, generating problems of compatibility and technological integration. Gatica (2018) concludes that the number of years of operation negatively affects the innovation rate, which can negatively affect the adoption of technologies 4.0. Therefore, the following hypotheses arise: 
H7: There is a positive relationship between the volume of sales and a larger scale of operation of companies that disseminate technologies 4.0 , increasing their diffusion power.

H8: There is a positive relationship between the total number of employees and the scale of operation of companies that disseminate technologies 4.0 , increasing their diffusion power.

H9: There is a negative relationship between the years of operation of companies that disseminate technologies 4.0 and these companies' scale of operation.

\section{METHODOLOGY}

This study applied second-order confirmatory factor analysis adopted in structural equation modeling, following previous research on innovation economy analyzing technology adoption (Agostini \& Filippini, 2019; Cabrera-Sánchez \& Villarejo-Ramos, 2019; Chauhan et al., 2021; Chege et al., 2020; Müller et al., 2018). However, few studies specifically consider structural equation modeling and the adoption of Industry technologies 4.0 (Kiraz et al., 2020). In this sense, this research contributes to filling a gap in the literature.

The model was developed using the data available in the Chilean Encuesta de Innovación and worked with three latent variables:

- Innovative Capacity (Innov): the innovative force explained by the variables past innovation, future innovation, the capacity to innovate based on the perception of challenge, percentage of employees who hold a graduate degree, percentage of qualified employees, and sales variation. The working hypothesis in this research suggests a positive relationship between innovative capacity and the capacity to disseminate technologies 4.0.

- Scale of operation (scale): refers to the companies' size. The explanatory variables are the volume of sales, the total number of employees, and the company's years of operation. The working hypothesis suggests a positive relationship between the company's operation scale and its diffusion power regarding technologies 4.0.

- Diffusion power (Diffusion). This latent variable represents the capacity of specialized suppliers and science-based companies to disseminate technologies 4.0 to other sectors of the economy nationwide. According to the model, the diffusion power positively depends on the companies' capacity to innovate and scale of operation.

Figure 1 presents the latent and explanatory variables. 
Figure 1. Relationship among explanatory variables of technology diffusion

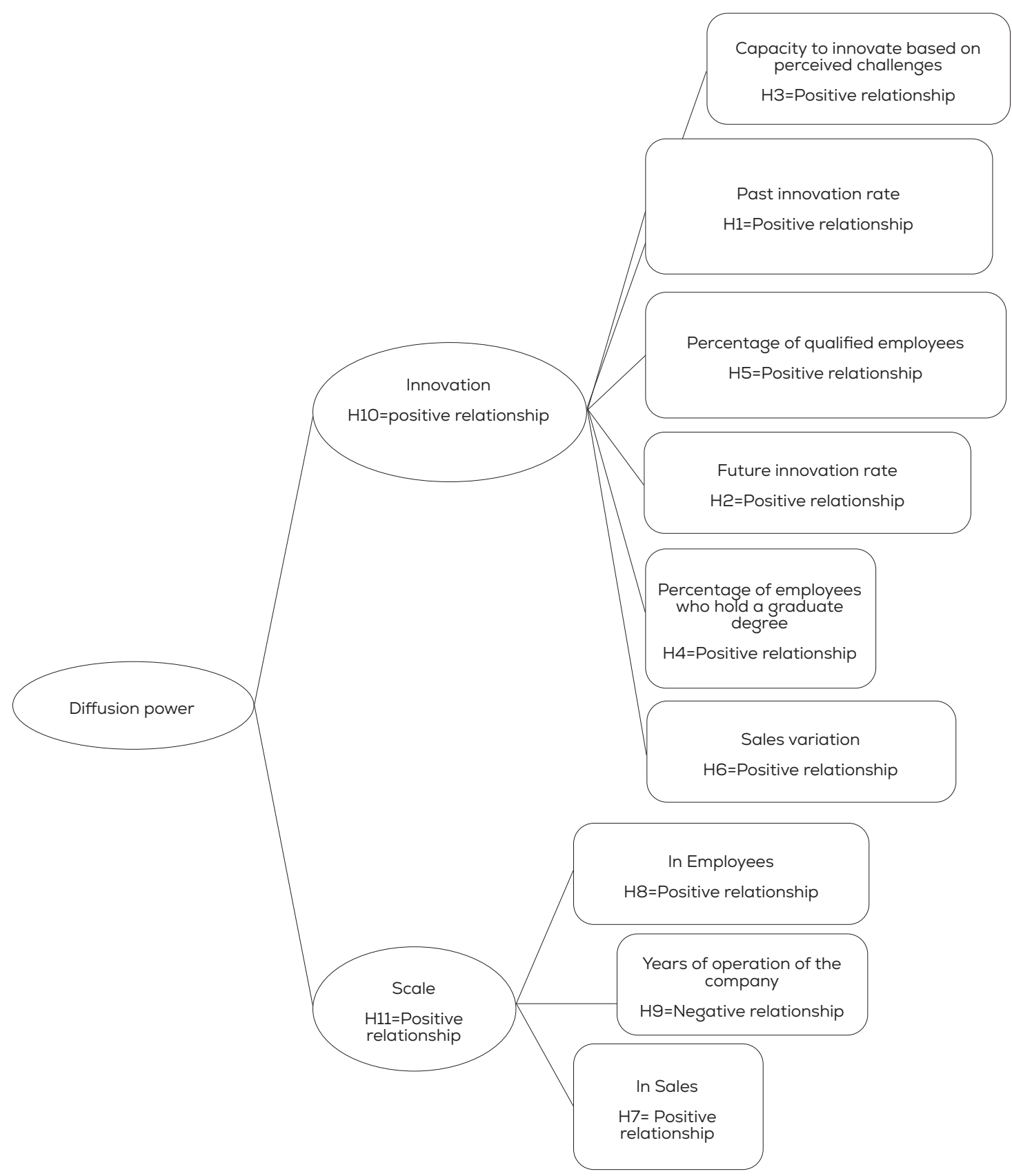


Exhibit 2 presents the explanatory variables, the metric from the information available in the Encuesta de Innovación, the explanation, and the expected relationship in the model based on the literature review.

Exhibit 2.Identification of the explanatory variables and formulation of the hypothetical relationship

\begin{tabular}{|c|c|c|c|}
\hline Explanatory variable & Metric & Explanation & $\begin{array}{l}\text { The hypothesis regarding } \\
\text { the latent variable and } \\
\text { references in the literature }\end{array}$ \\
\hline $\begin{array}{l}\text { Past innovation rate } \\
\text { (Pinn) }\end{array}$ & $\begin{array}{l}=[\Sigma \text { score by company i (New } \\
\text { goods + New services + } \\
\text { Improved production method } \\
+ \text { Improved logistics method } \\
+ \text { Improved support + New } \\
\text { practices of organizational } \\
\text { process + New methods of } \\
\text { organizational responsibility } \\
+ \text { New methods of external } \\
\text { organizational relations + } \\
\text { Changes in packaging design } \\
+ \text { New means of promotion + } \\
\text { New methods for distribution } \\
\text { channels + New pricing } \\
\text { methods + Social innovation) / } \\
\Sigma \text { maximum score }{ }^{*} 100\end{array}$ & $\begin{array}{l}\text { The company that presents a } \\
\text { higher past innovation rate } \\
\text { is more likely to incorporate } \\
\text { technologies } 4.0 \text { and to } \\
\text { contribute to their diffusion }\end{array}$ & $\begin{array}{l}\text { H1: Positive relationship }(+) \\
\text { between the past innovation } \\
\text { rate and innovative capacity } \\
\text { Horváth et al. (2019), } \\
\text { Chauhan et al. (2021), Müller } \\
\text { et al. (2018), Agostini et al. } \\
\text { (2019), Rojas-Córdova et al. } \\
(2020)\end{array}$ \\
\hline $\begin{array}{l}\text { Future innovation perspective } \\
\text { (Finn) }\end{array}$ & $\begin{array}{l}=\Sigma \text { of future innovation } \\
\text { present in (product }+ \text { process } \\
+ \text { MKT + organizational } \\
\text { management + social) }{ }^{*} 100\end{array}$ & $\begin{array}{l}\text { The company with more } \\
\text { expectations of generating } \\
\text { innovation on different fronts } \\
\text { of organizational development } \\
\text { has a greater capacity to } \\
\text { disseminate technologies } 4.0\end{array}$ & $\begin{array}{l}\text { H2: Positive relationship (+) } \\
\text { between plans for future } \\
\text { innovation projects and } \\
\text { innovative capacity } \\
\text { Horváth et al. (2019), } \\
\text { Chauhan et al. (2021), Müller } \\
\text { et al. (2018), Agostini et al. } \\
\text { (2019), Botha (2019) }\end{array}$ \\
\hline $\begin{array}{l}\text { Capacity to innovate based } \\
\text { on perceived challenges } \\
\text { (InnChall) }\end{array}$ & $\begin{array}{l}=1-[[\Sigma \text { score by company } i \\
\text { (Lack of own funds + Lack of } \\
\text { external funding + Very high } \\
\text { cost of innovation + Lack of } \\
\text { qualified personnel + Lack } \\
\text { of technology information } \\
+ \text { Lack of information on } \\
\text { markets + Difficulty finding a } \\
\text { partner + Market dominated } \\
\text { by established companies + } \\
\text { Uncertainty regarding the } \\
\text { demand for goods + Not } \\
\text { necessary due to previous } \\
\text { innovation + Not necessary } \\
\text { due to lack of demand for } \\
\text { innovation + Regulatory } \\
\text { challenges) / } \Sigma \text { maximum } \\
\left.\text { score] }{ }^{*} 100\right]\end{array}$ & $\begin{array}{l}\text { The greater the perception } \\
\text { of innovation facilities, the } \\
\text { greater the capacity to } \\
\text { innovate }\end{array}$ & $\begin{array}{l}\text { H3: Positive relationship (+) } \\
\text { between the capacity to } \\
\text { innovate based on perceived } \\
\text { challenges and innovative } \\
\text { capacity. } \\
\text { Reyes et al. (2016), Arnold et } \\
\text { al. (2018), Cabrera-Sánchez } \\
\text { (2019), Chege et al. (2020), } \\
\text { Horváth et al. (2019), Kiraz } \\
\text { et al. (2020), Agostini et al. } \\
\text { (2019) }\end{array}$ \\
\hline
\end{tabular}


Exhibit 2.Identification of the explanatory variables and formulation of the hypothetical relationship

\begin{tabular}{|c|c|c|c|}
\hline Explanatory variable & Metric & Explanation & $\begin{array}{l}\text { The hypothesis regarding } \\
\text { the latent variable and } \\
\text { references in the literature }\end{array}$ \\
\hline $\begin{array}{l}\text { Percentage of employees who } \\
\text { hold a graduate degree } \\
\text { (PerEmpGrad) }\end{array}$ & $\begin{array}{l}=[(\text { Number of employees who } \\
\text { hold masters or PhD degrees } \\
\text { / Total number of employees })] \\
\text { * } 100\end{array}$ & $\begin{array}{l}\text { Having employees who hold } \\
\text { a graduate degree increases } \\
\text { the probability of innovation, } \\
\text { facilitating technological } \\
\text { diffusion }\end{array}$ & $\begin{array}{l}\text { H4: Positive relationship (+) } \\
\text { between the percentage } \\
\text { of employees who hold } \\
\text { a graduate degree and } \\
\text { innovative capacity } \\
\text { Ingaldi et al. (2020), } \\
\text { Dalenogarea et al. (2018), } \\
\text { Reyes et al. (2016), Vowles et } \\
\text { al. (2011), Chege et al (2020), } \\
\text { Agostini et al. (2019) }\end{array}$ \\
\hline $\begin{array}{l}\text { Percentage of qualified } \\
\text { employees } \\
\text { (PerQualEmp) }\end{array}$ & $\begin{array}{l}=((\text { Number of specialized } \\
\text { employees } / \text { Total number of } \\
\text { employees }))^{*} 100\end{array}$ & $\begin{array}{l}\text { Having qualified employees } \\
\text { increases the probability of } \\
\text { innovating }\end{array}$ & $\begin{array}{l}\text { H5: Positive relationship (+) } \\
\text { between the percentage } \\
\text { of qualified employees and } \\
\text { innovative capacity } \\
\text { Ingaldi et al. (2020), } \\
\text { Dalenogarea et al. (2018), } \\
\text { Reyes et al. (2016), } \\
\text { Vowles et al. (2011), Chege et } \\
\text { al. (2020) }\end{array}$ \\
\hline $\begin{array}{l}\text { Sales variation } \\
\text { (SalesVari) }\end{array}$ & $\begin{array}{l}=[((\text { Sales } \$ 2016-\text { sales } \$ 2015) \\
/ \text { Sales } \$ 2015)]^{*} 100\end{array}$ & $\begin{array}{l}\text { An increase in sales can } \\
\text { generate an incentive to } \\
\text { adopt technology }\end{array}$ & $\begin{array}{l}\text { H6: Positive relationship (+) } \\
\text { between the sales variation } \\
\text { and the innovative capacity } \\
\text { Prause et al. (2019), Reyes et } \\
\text { al. (2016) }\end{array}$ \\
\hline $\begin{array}{l}\text { Sales volume } \\
\text { (InSales) }\end{array}$ & $\begin{array}{l}\text { Natural logarithm of sales } \\
\text { volume (\$) }\end{array}$ & $\begin{array}{l}\text { The larger the sales volume, } \\
\text { the greater the diffusion } \\
\text { effect, since the company's } \\
\text { size facilitates technology } \\
\text { adoption) }\end{array}$ & $\begin{array}{l}\text { H7: Positive relationship (+) } \\
\text { between the volume of sales } \\
\text { and the scale of operation of } \\
\text { companies that disseminate } \\
\text { technologies } 4.0 \\
\text { Ingaldi et al. (2020), Reyes et } \\
\text { al. (2016), Kiraz et al. (2020 }\end{array}$ \\
\hline $\begin{array}{l}\text { Total number of employees } \\
\text { (InTotEmp) }\end{array}$ & $\begin{array}{l}\text { Natural logarithm of the } \\
\text { number of employees }\end{array}$ & $\begin{array}{l}\text { The larger the company, the } \\
\text { greater its diffusion power. }\end{array}$ & $\begin{array}{l}\text { H8: Positive relationship (+) } \\
\text { between the total number of } \\
\text { employees and the scale of } \\
\text { operation of companies that } \\
\text { disseminate technologies } 4.0 \\
\text { Ingaldi et al. (2020), Reyes et } \\
\text { al. (2016), Chege et al. (2020), } \\
\text { Brambilla (2018) }\end{array}$ \\
\hline $\begin{array}{l}\text { Years of operation } \\
\text { (CompYear) }\end{array}$ & $\begin{array}{l}\text { Years of operation of the } \\
\text { company }\end{array}$ & $\begin{array}{l}\text { The number of years since } \\
\text { the company started its } \\
\text { operations. The lower diffusion } \\
\text { capacity is due to difficulties } \\
\text { in adapting to new production } \\
\text { models }\end{array}$ & $\begin{array}{l}\text { H9: Negative relationship } \\
\text { (-) between the years of } \\
\text { operation of companies that } \\
\text { disseminate technologies } 4.0 \\
\text { and these companies' scale of } \\
\text { operation } \\
\text { Ingaldi et al. (2020), Gatica } \\
\text { (2018) }\end{array}$ \\
\hline
\end{tabular}


As mentioned above, the distribution presented by the variables does not meet the assumptions of multivariate normality, and specific models for ordinal variables were adopted (Jöreskog, 1994). In addition, Pearson, polychoric, and polyserial correlation matrices were used (Table 1). The analysis adopted a diagonal weighted least squares (DWLS) robust estimation method, included in the Lisrel 8.8 system and specially designed for ordinal variables.

Table 1. Correlation matrix

\begin{tabular}{|c|c|c|c|c|c|c|c|c|c|}
\hline & InnChall & Finn & CompYear & InSales & SalesVari & InTotEmp & PerEmpGrad & PerQualEmp & Pinn \\
\hline InnChall & 1.00 & & & & & & & & \\
\hline Finn & $\begin{array}{l}0.01 \\
\text { (PS) }\end{array}$ & 1.00 & & & & & & & \\
\hline CompYear & $\begin{array}{l}0.04 \\
(P E)\end{array}$ & $\begin{array}{r}-0.07 \\
(P S)\end{array}$ & 1.00 & & & & & & \\
\hline InSales & $\begin{array}{l}0.19 \\
\text { (PS) }\end{array}$ & $\begin{array}{c}0.11 \\
(P C)\end{array}$ & $\begin{array}{l}0.26 \\
\text { (PS) }\end{array}$ & 1.00 & & & & & \\
\hline SalesVari & $\begin{array}{l}0.08 \\
(P E)\end{array}$ & $\begin{array}{l}0.05 \\
\text { (PS) }\end{array}$ & $\begin{array}{r}-0.09 \\
(P E)\end{array}$ & $\begin{array}{l}0.16 \\
\text { (PS) }\end{array}$ & 1.00 & & & & \\
\hline InTotEmp & $\begin{array}{l}0.14 \\
\text { (PS) }\end{array}$ & $\begin{array}{l}0.13 \\
(P C)\end{array}$ & $\begin{array}{l}0.25 \\
\text { (PS) }\end{array}$ & $\begin{array}{l}0.80 \\
(P C)\end{array}$ & $\begin{array}{l}0.09 \\
\text { (PS) }\end{array}$ & 1.00 & & & \\
\hline PerEmpGrad & $\begin{array}{r}-0.02 \\
(P E)\end{array}$ & $\begin{array}{l}0.02 \\
\text { (PS) }\end{array}$ & $\begin{array}{r}-0.07 \\
(P E)\end{array}$ & $\begin{array}{r}-0.02 \\
(P S)\end{array}$ & $\begin{array}{l}0.09 \\
(P E)\end{array}$ & $\begin{array}{r}-0.06 \\
(P S)\end{array}$ & 1.00 & & \\
\hline PerQualEmp & $\begin{array}{l}0.09 \\
(P E)\end{array}$ & $\begin{array}{l}0.20 \\
\text { (PS) }\end{array}$ & $\begin{array}{r}-0.15 \\
(P E)\end{array}$ & $\begin{array}{r}-0.05 \\
(P S)\end{array}$ & $\begin{array}{r}-0.03 \\
(P E)\end{array}$ & $\begin{array}{r}-0.13 \\
(P S)\end{array}$ & $\begin{array}{r}-0.01 \\
(P E)\end{array}$ & 1.00 & \\
\hline Pinn & 0.20 (PS) & $\begin{array}{l}0.58 \\
(P C)\end{array}$ & $\begin{array}{r}-0.12 \\
(P S)\end{array}$ & $\begin{array}{l}0.23 \\
(P C)\end{array}$ & -0.03 (PS) & $\begin{array}{l}0.26 \\
(P C)\end{array}$ & $\begin{array}{l}0.06 \\
\text { (PS) }\end{array}$ & $\begin{array}{l}0.20 \\
\text { (PS) }\end{array}$ & 1.00 \\
\hline
\end{tabular}

Note: The type of correlation is show in brackets: $\mathrm{PE}=$ Pearson, $\mathrm{PC}=$ Polychoric, $\mathrm{PS}=$ Polyserial Source: Elaborated by the authors based on Lisrel results.

Tables 3 and 5 present different criteria to measure the quality of the models. The following indices are distinguished: goodness of fit, incremental fit, and parsimony fit. Considering the large sample analyzed, the ratio between chi-square and degrees of freedom is presented (Hooper, Coughlan, \& Mullen, 2008).

The analysis started with 373 companies. After eliminating incomplete and erratic data, the final sample consisted of 313 companies (83\% of the original number). The study encompasses 12 variables (latent and explanatory). Therefore, there is a ratio of 26.08 companies per variable, which is above the minimum required in this type of study (15 units per variable) (Hair, Andersen, Tathan, \& Black, 1999). 


\section{RESULTS}

A preliminary review of data is presented here to contextualize the final results. Subsequently, the first and second models are developed.

\section{Preliminary review of data}

Table 2 presents the indicators for the type of future and past innovation and obstacles to innovation perceived by companies that diffuse technologies 4.0.

Table 2. Distribution of types of future and past innovation and challenges to innovation

\begin{tabular}{|c|c|c|c|}
\hline & & $\begin{array}{l}\text { Number of } \\
\text { companies }\end{array}$ & $\begin{array}{c}\text { Percentage ( } 313 \\
\text { companies) }\end{array}$ \\
\hline \multirow{7}{*}{$\begin{array}{l}\text { Future innovation } \\
\text { (a company may } \\
\text { intend to innovate in } \\
\text { more than one area) }\end{array}$} & Future product innovation & 162 & $51.6 \%$ \\
\hline & Future process innovation & 132 & $42.2 \%$ \\
\hline & Does not contemplate innovation in the future & 115 & $36.6 \%$ \\
\hline & Future innovation in organizational management & 100 & $32.0 \%$ \\
\hline & Future innovations in MKT & 94 & $30.1 \%$ \\
\hline & Future innovations of a social nature & 40 & $12.6 \%$ \\
\hline & & $\begin{array}{l}\text { Number of } \\
\text { companies }\end{array}$ & $\begin{array}{c}\text { Percentage ( } 313 \\
\text { companies) }\end{array}$ \\
\hline \multirow{14}{*}{$\begin{array}{l}\text { Past innovation } \\
\text { (a company may } \\
\text { have innovated in } \\
\text { more than one area) }\end{array}$} & It does not feature past innovation & 213 & $68.0 \%$ \\
\hline & New services & 49 & $15.6 \%$ \\
\hline & New practices of process organization. & 47 & $15.1 \%$ \\
\hline & New methods of organizing responsibilities & 44 & $14.0 \%$ \\
\hline & Improve support & 40 & $12.7 \%$ \\
\hline & Improved production method & 34 & $10.8 \%$ \\
\hline & New goods & 31 & $10.0 \%$ \\
\hline & New means of promotion. & 27 & $8.6 \%$ \\
\hline & New methods of external relations & 25 & $8.1 \%$ \\
\hline & New pricing methods & 23 & $7.3 \%$ \\
\hline & New methods for distribution channels & 19 & $6.2 \%$ \\
\hline & Changes in packaging design & 18 & $5.7 \%$ \\
\hline & Improved logistics method & 13 & $4.0 \%$ \\
\hline & Social innovation & 6 & $1.9 \%$ \\
\hline
\end{tabular}

(Continue) 
Table 2. Distribution of types of future and past innovation and challenges to innovation

\begin{tabular}{|c|c|c|c|}
\hline & & $\begin{array}{l}\text { Number of } \\
\text { companies }\end{array}$ & $\begin{array}{c}\text { Percentage ( } 313 \\
\text { companies) }\end{array}$ \\
\hline & & $\begin{array}{l}\text { Number of } \\
\text { companies }\end{array}$ & $\begin{array}{c}\text { Percentage on a } 313 \\
\text { basis }\end{array}$ \\
\hline \multirow{12}{*}{$\begin{array}{l}\text { Main barriers } \\
\text { to innovate (a } \\
\text { company may } \\
\text { appoint more than } \\
\text { one item) }\end{array}$} & High costs of innovation & 128 & $41.0 \%$ \\
\hline & Lack of own funds & 127 & $40.7 \%$ \\
\hline & Lack of external funding & 101 & $32.3 \%$ \\
\hline & A market dominated by established companies & 94 & $30.2 \%$ \\
\hline & Uncertainty regarding the demand for goods & 94 & $30.2 \%$ \\
\hline & Difficulty finding a partner & 83 & $26.4 \%$ \\
\hline & Lack of qualified personnel & 68 & $21.8 \%$ \\
\hline & Lack of technology information & 53 & $17.0 \%$ \\
\hline & Lack of market information & 52 & $16.7 \%$ \\
\hline & Regulatory barriers & 40 & $12.9 \%$ \\
\hline & Lack of demand for innovation & 30 & $9.7 \%$ \\
\hline & Innovation is not required due to previous innovations & 30 & $9.4 \%$ \\
\hline
\end{tabular}

(Concludes)

Of the companies analyzed, 36.6\% do not contemplate innovating in the next two years. In the distribution of the innovation types: the "product innovation" present in $51.6 \%$ of the companies, and the "process innovation" with a participation of $42.2 \%$, stand out. With a similar weight are the innovations in "marketing" and "organizational management" - 30.1\% and $32.0 \%$, respectively. Finally, there are those of a "social nature" with $12.6 \%$.

Regarding innovation in the previous two years, it is interesting that $68 \%$ of the companies did not innovate at all. Compared to companies that want to innovate in the future $(63.3 \%)$ with those that innovated in the previous two years $(32.0 \%)$, there is a problem of innovative efficiency where many companies do not innovate, even though they intend to. The innovation rate of previous years $(32.0 \%)$ is above the similar national average of $23.6 \%$ (Gatica, 2019).

New services stand out among past innovations (observed in $15.6 \%$ of the companies). Process innovation appears after, observed in $15.1 \%$, followed by changes in the form of organization (14\% of companies).

The biggest obstacle observed is financial. The high cost of innovation and the lack of funds to meet requirements are present in about $41 \%$. Similarly, 32.3\% of the companies that diffuse technologies 4.0 perceive difficulty obtaining external financing.

Three factors showed a lower level of relevance regarding structural variables in the sector. Of the companies analyzed, 30.2\% mentioned that established companies dominate the market, and a similar percentage believe that the uncertainty regarding the demand for new goods slows innovation. 
These results show the relevance of having resources to support the risk involved in undertaking an innovation process.

\section{First model}

Table 3 presents the main indicators of goodness of fit, incremental adjustment measures, and parsimony adjustment, comparing them with the reference parameters normally used in the literature (Escobedo, Hernández, Estabané, \& Martínez, 2016; Hair et al., 1999).

Table 3. The goodness of fit of the first model

\begin{tabular}{|c|c|c|c|c|}
\hline Types of Settings & Statistics & $\begin{array}{l}\text { Observed value } \\
\text { First Model }\end{array}$ & Reference value & Fit quality \\
\hline \multirow{4}{*}{$\begin{array}{l}\text { Goodness-of-fit } \\
\text { Indexes }\end{array}$} & $\begin{array}{l}\text { Root Mean Square Error of } \\
\text { Approximation (RMSEA) }\end{array}$ & 0.00 & $<0.08$ & Acceptable \\
\hline & Standardized RMR & 0.07 & $<0.7$ and $\mathrm{CFI}>0.92$ & Acceptable \\
\hline & Root Mean Square Residual (RMR) & 0.07 & $<0.7$ and $\mathrm{CFI}>0.92$ & Acceptable \\
\hline & Chi square / degrees of freedom & $=(74.09 / 26)=2.84$ & Between 2-5 & Acceptable \\
\hline \multirow{3}{*}{$\begin{array}{l}\text { Incremental fit } \\
\text { Indexes }\end{array}$} & Normed Fit Index (NFI) & 1.00 & $>0.92$ & Acceptable \\
\hline & Comparative Fit Index (CFI) & 1.00 & $>0.95$ & Acceptable \\
\hline & $\begin{array}{l}\text { Adjusted Goodness of Fit Index } \\
\text { (AGFI) }\end{array}$ & 0.96 & $>0.90$ & Acceptable \\
\hline $\begin{array}{l}\text { Parsimony fit -- } \\
\text { Indexes }\end{array}$ & Parsimony Normed Fit Index (PNFI) & 0.72 & $\begin{array}{l}\text { Between } 0.5 \text { and } 0.7 \text {, } \\
\text { considered acceptable }\end{array}$ & Out of range \\
\hline
\end{tabular}

Table 3 shows that the proposed model presents acceptable conditions to be analyzed. The parsimony fit is outside the accepted range. However, Newsom (2018), suggests evaluating the model independently of the parsimony fit. At the time of the analysis, the proposed model was convergent. 
Francisco Gatica-Neira

Figure 2. First Model

Standardized factorial loads $(\lambda n)$ and estimation errors (e).

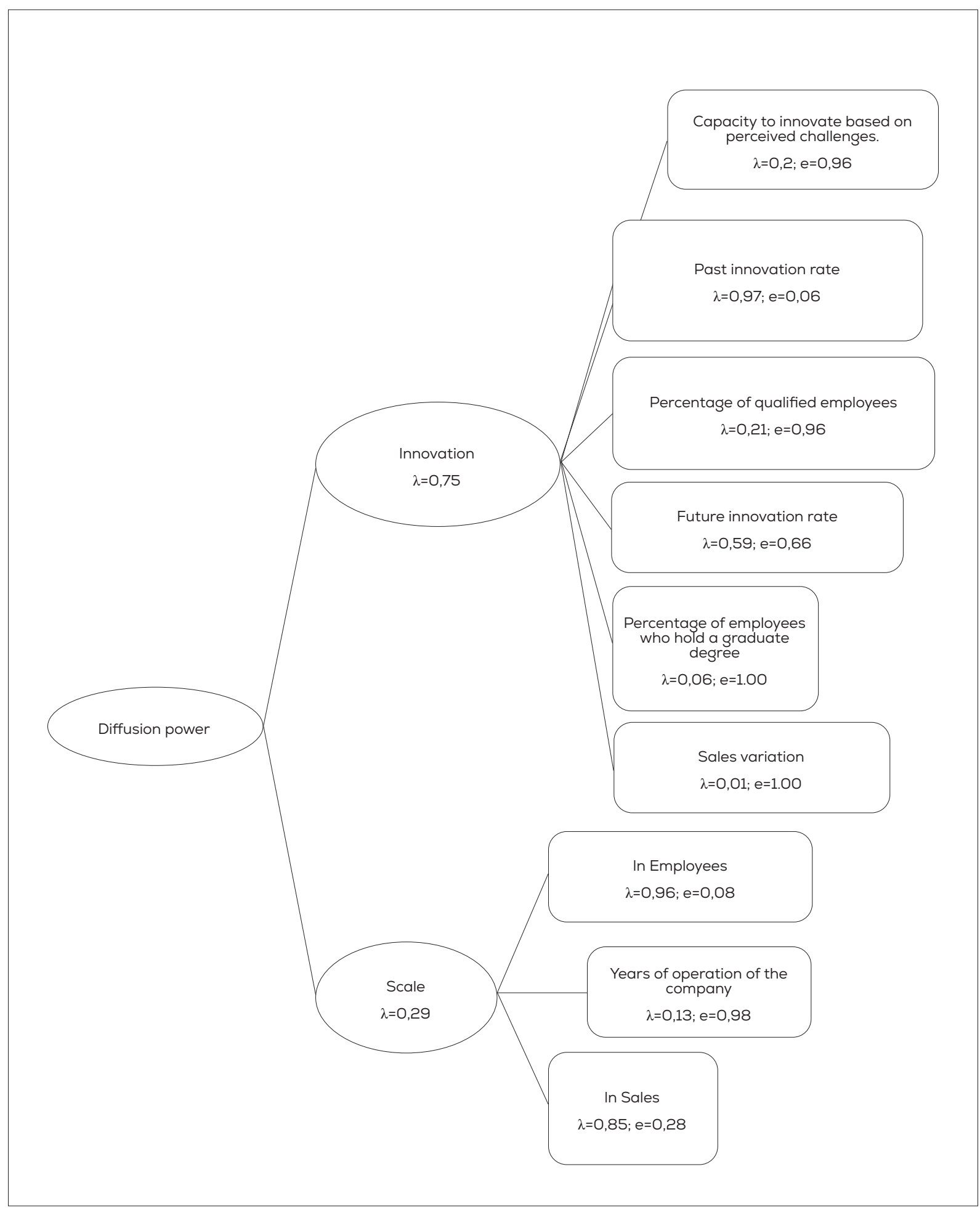


Table 4. Results of the first model, by variable

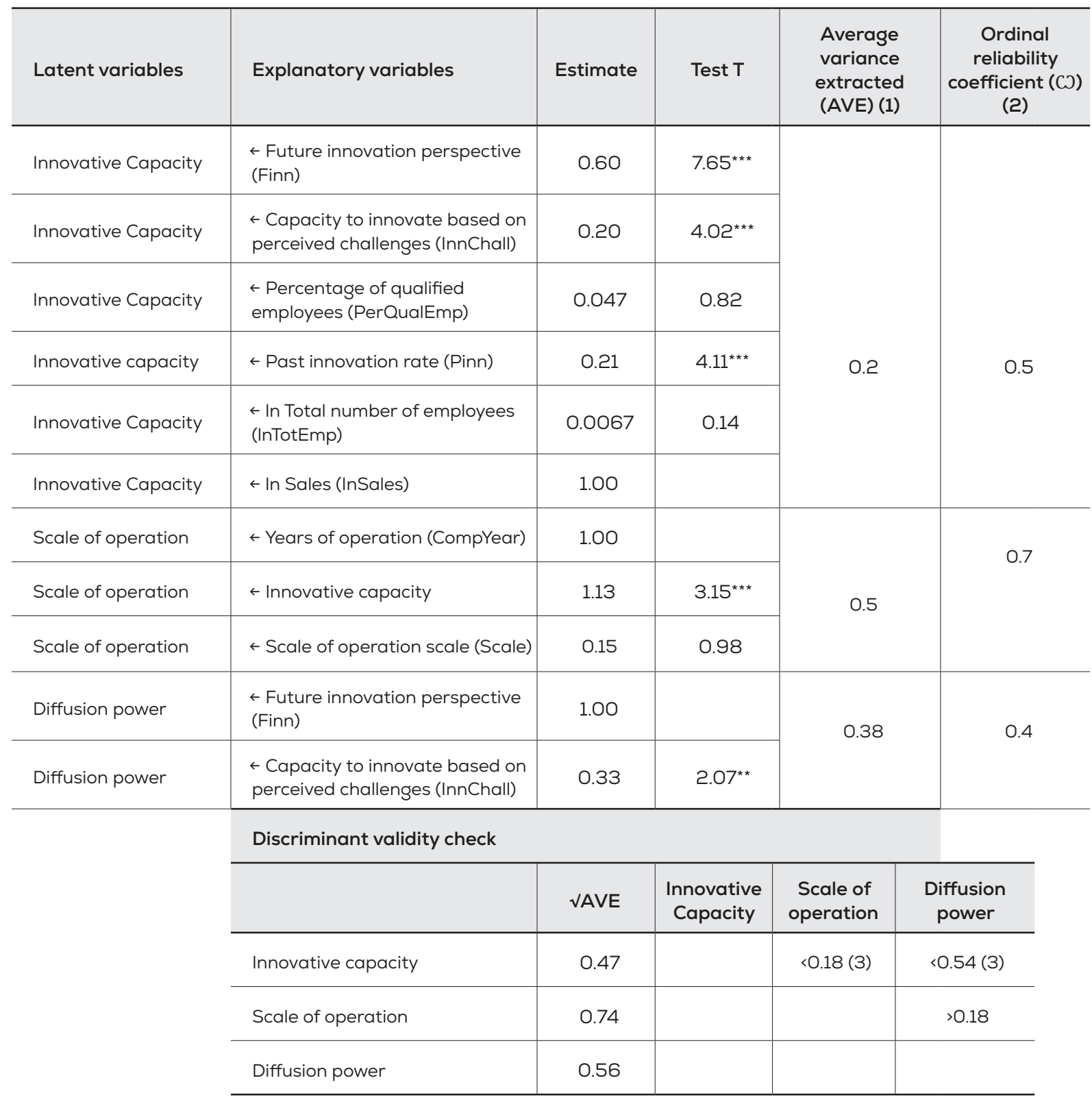

$\left.{ }^{* * *}\right) 99 \%$ confidence; $\left(^{* *}\right) 95 \%$ confidence and $\left(^{*}\right) 90 \%$ confidence.

Note $1=$ Average variance extracted $(A V E)=\left[\left(\Sigma \lambda^{2}\right) / n\right]$; where $n$ is the number of indicators.

Note 2 = Ordinal reliability coefficient $(\omega)=\left[(\Sigma \lambda)^{2} /\left((\Sigma \lambda)^{2}+\left(\Sigma 1-\lambda^{2}\right)\right]\right.$

Note $3=$ Low discriminant capacity of the latent variable.

Figure 2 presents the first model. The latent variables innovation and scale of operation explain the "diffusion power" (Table 4). From the standardized factorial loads (herein $\lambda$ ), the innovative capacity $(\lambda=0.75)$ is greater than the operation scale $(\lambda=0.29)$.

Among the explanatory variables for innovation, the percentage of employees with a graduate degree showed little significance $(\lambda=0.06$; $t=0.82)$, rejecting hypothesis $\mathrm{H} 4$. However, the 
percentage of qualified employees was found as highly explanatory of the companies' innovation capacity $(\lambda=0.21 ; \mathrm{t}=4.11)$, proving hypothesis $\mathrm{H} 5$ and justifying the intensive learning in the organizations.

The capacity to innovate based on challenges perceived is positively correlated with diffusion power $(\lambda=0.20 ; t=4.02)$, confirming hypothesis $\mathrm{H} 3$. Also, the positive relationship between future innovation, innovation capacity, and, consequently, the diffusion power of the company $(\lambda=0.59, \mathrm{t}=7.65)$ was observed, confirming $\mathrm{H} 2$.

Compared to the previous year, the improvement in sales does not present a significant relationship with the innovation capacity $(\lambda=0.01 ; \mathrm{t}=0.14)$, rejecting hypothesis H6. Therefore, this factor is not relevant when analyzing a company's diffusion power.

Finally, the past innovation rate variable $(\lambda=0.97)$ was set at a unit value to run the confirmatory factor analysis. The relationship with the latent variable was positive from its factorial load, confirming hypothesis $\mathrm{Hl}$.

The analysis of the second latent variable demonstrated that the number of employees $(\lambda$ $=0.96, t=3.15)$ has a significantly positive relationship with the company's scale of operation and, therefore, with its diffusion power. This result corroborates hypothesis H8.

In this first model, there was no significative relation between the variable years of operation and the scale of operation of companies disseminating technologies $4.0(\lambda=0.13$; $t=0.98)$, rejecting hypothesis $\mathrm{H} 9$.

Finally, the sales volume had a positive relationship with the scale of operation $(\lambda=0.85)$ of companies that disseminate technologies 4.0, confirming hypothesis H7. This variable was determined in a unit value to run the confirmatory factor analysis and is consistent with the model.

From this first model, it is possible to observe that the diffusion power is greater when there is: i) a more significant number of projects for innovation in the future; ii) more employees; iii) more qualified employees; iv) capacity to innovate based on perceived challenges.

Table 6 also shows the average extracted variance (AVE), the ordinal reliability coefficient (C)), and the discriminant validity (Elosua \& Zumbo, 2008; McDonald \& Ho, 2002; Ventura-León \& Caycho-Rodríguez, 2017; Viladrich, Angulo-Brunet, \& Doval, 2017). The reliability for ordinal variables $(\mathrm{CD})$ was 0.5 and 0.7 for the two latent variables, which is acceptable. However, in the first model, the construct "innovative capacity" had a low discriminant capacity; in both cases, the square root of the AVE was less than the correlation of the construct.

\section{Second model}

The second model presents improvements in comparison to the first model developed. The construct "innovative capacity" was given discriminant validity, excluding variables that did not present a significant relationship in the first model $(t<1.96,95 \%$ confidence). Therefore, sales variation and the percentage of employees who hold a graduate degree were eliminated. Table 5 shows that the second model has incremental and parsimony goodness of fit, correcting the first model. 
Table 5. The goodness of fit of the second model

\begin{tabular}{|c|c|c|c|c|}
\hline Types of Settings & Statistics & $\begin{array}{c}\text { Improved } \\
\text { observed value }\end{array}$ & Reference value & Quality of fit. \\
\hline \multirow{4}{*}{ Goodness-of-fit Indexes } & $\begin{array}{l}\text { Root Mean Square Error of } \\
\text { Approximation (RMSEA) }\end{array}$ & 0.00 & $<0.08$ & Acceptable \\
\hline & Standardized RMR & 0.06 & $<0.7$ con $\mathrm{CFI}>0.92$ & Acceptable \\
\hline & Root Mean Square Residual (RMR) & 0.06 & $<0.7$ con $\mathrm{CFI}>0.92$ & Acceptable \\
\hline & Chi square / degrees of freedom & $=(41.9 / 12)=3.4$ & Between 2-5 & Acceptable \\
\hline \multirow{3}{*}{$\begin{array}{l}\text { Incremental fit indices } \\
\text { Indexes }\end{array}$} & Normed Fit Index (NFI) & 1.00 & About 0.92 & Acceptable \\
\hline & Comparative Fit Index (CFI) & 1.00 & About 0.95 & Acceptable \\
\hline & Adjusted Goodness of Fit Index (AGFI) & 0.97 & $>0.90$ & Acceptable \\
\hline $\begin{array}{l}\text { Parsimony fit indices } \\
\text { Indexes }\end{array}$ & Parsimony Normed Fit Index (PNFI) & 0.57 & $\begin{array}{l}\text { Between } 0.5 \text { and } \\
0.7 \text { is considered } \\
\text { acceptable }\end{array}$ & Acceptable \\
\hline
\end{tabular}

Figure 3. Second Model

Standardized factorial loads $(\lambda n)$ and estimation errors (e).

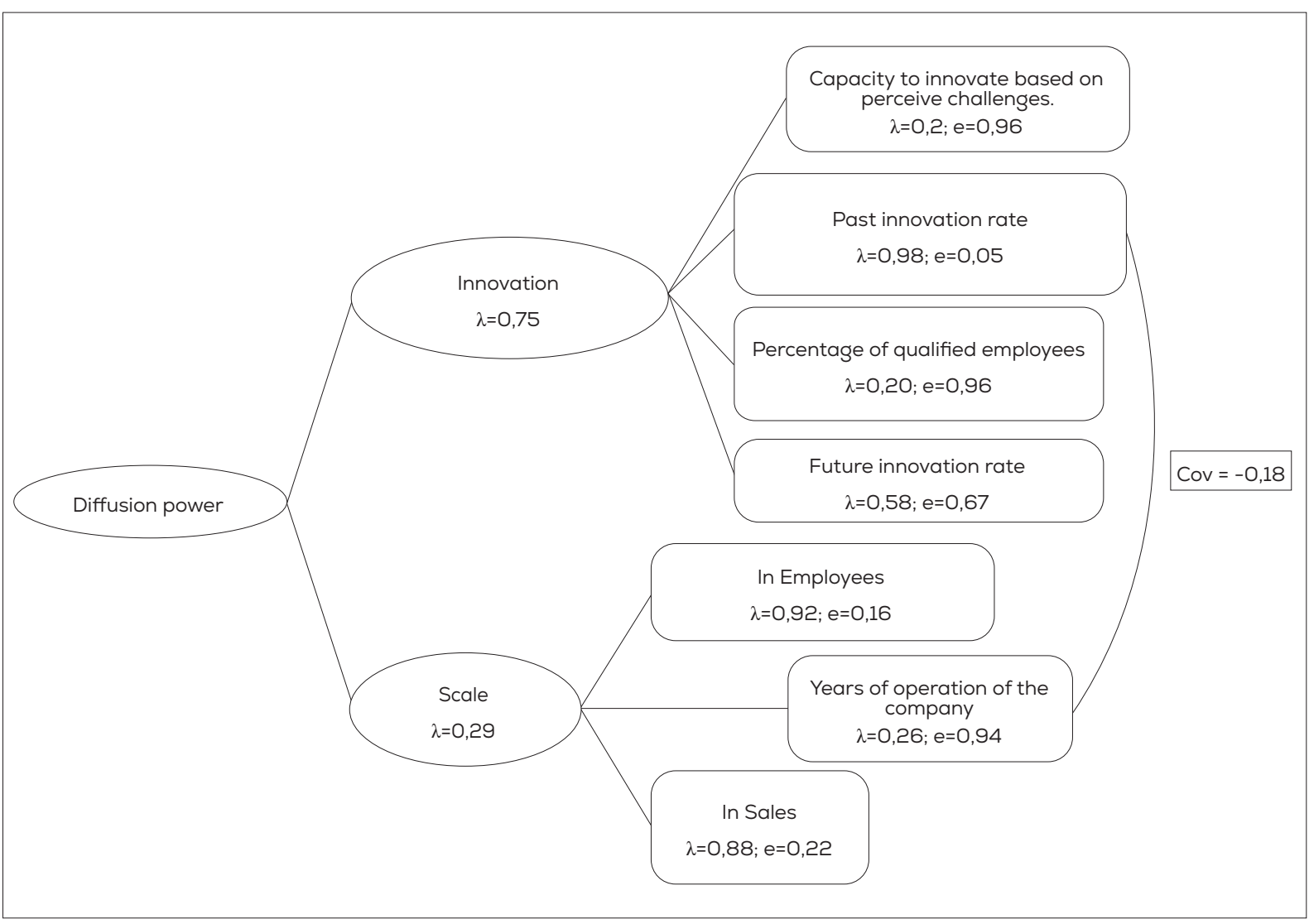


Table 6. Results of the second model, by variable

\begin{tabular}{|c|c|c|c|c|c|c|}
\hline $\begin{array}{l}\text { Latent } \\
\text { variables }\end{array}$ & Explanatory variables & Estimate & Test T & \multicolumn{2}{|c|}{$\begin{array}{c}\text { Average variance } \\
\text { extracted } \\
(\text { AVE })(1)\end{array}$} & $\begin{array}{l}\text { Ordinal reliability } \\
\text { coefficient } \\
\text { (C) (2) }\end{array}$ \\
\hline $\begin{array}{l}\text { Innovative } \\
\text { Capacity }\end{array}$ & $\begin{array}{l}\leftarrow \text { Future innovation } \\
\text { perspective (Finn) }\end{array}$ & 0.59 & $7.56^{* * *}$ & \multirow{4}{*}{\multicolumn{2}{|c|}{0,4}} & \multirow{4}{*}{0.6} \\
\hline $\begin{array}{l}\text { Innovative } \\
\text { Capacity }\end{array}$ & $\begin{array}{l}\leftarrow \text { Capacity to innovate } \\
\text { based on perceived } \\
\text { challenges (InnChall) }\end{array}$ & 0.20 & $3.99^{* * *}$ & & & \\
\hline $\begin{array}{l}\text { Innovative } \\
\text { capacity }\end{array}$ & $\begin{array}{l}\leftarrow \text { Percentage of } \\
\text { qualified employees } \\
\text { (PerQualEmp) }\end{array}$ & 0.21 & $4.03^{* * *}$ & & & \\
\hline $\begin{array}{l}\text { Innovative } \\
\text { Capacity }\end{array}$ & $\begin{array}{l}\leftarrow \text { Past innovation rate } \\
\text { (Pinn) }\end{array}$ & 1.00 & & & & \\
\hline $\begin{array}{l}\text { Operation } \\
\text { scale }\end{array}$ & $\begin{array}{l}\leftarrow \text { In Total number of } \\
\text { employees (InTotEmp) }\end{array}$ & 1.04 & $5.72^{* * *}$ & \multirow{3}{*}{\multicolumn{2}{|c|}{0.6}} & \multirow{3}{*}{0.8} \\
\hline $\begin{array}{l}\text { Operation } \\
\text { scale }\end{array}$ & $\leftarrow$ In Sales (InSales) & 1.00 & & & & \\
\hline $\begin{array}{l}\text { Operation } \\
\text { scale }\end{array}$ & $\begin{array}{l}\leftarrow \text { Years of operation } \\
\text { (CompYear) }\end{array}$ & 0.29 & $2.80^{* * *}$ & & & \\
\hline $\begin{array}{l}\text { Diffusion } \\
\text { power }\end{array}$ & $\leftarrow$ Innovative capacity & 1.00 & & \multirow{2}{*}{\multicolumn{2}{|c|}{0.3}} & \multirow[b]{2}{*}{0.5} \\
\hline $\begin{array}{l}\text { Diffusion } \\
\text { power }\end{array}$ & $\begin{array}{l}\leftarrow \text { Scale of operation } \\
\text { scale (Scale) }\end{array}$ & 0.42 & $3.74^{* \star *}$ & & & \\
\hline \multicolumn{7}{|c|}{ Discriminant validity check } \\
\hline & & VAVE & $\begin{array}{l}\text { Innovative } \\
\text { capacity }\end{array}$ & $\begin{array}{l}\text { Scale of } \\
\text { operation }\end{array}$ & \multicolumn{2}{|c|}{ Diffusion power } \\
\hline & Capacidad innovativa & 0.63 & & $>0.21$ & \multicolumn{2}{|c|}{$>0.51$} \\
\hline & Escala de operación & 0.77 & & & \multicolumn{2}{|c|}{$>0.21$} \\
\hline & Potencia difusora & 0.56 & & & & \\
\hline
\end{tabular}

$\left.{ }^{* * *}\right) 99 \%$ confidence; $\left(^{* *}\right) 95 \%$ confidence and $\left(^{*}\right) 90 \%$ confidence.

Note $1=$ Average variance extracted $(\operatorname{AVE})=\left[\left(\Sigma \lambda^{2}\right) / n\right]$; where $n$ is the number of indicators.

Note $2=$ Ordinal reliability coefficient $(\omega)=\left[(\Sigma \lambda)^{2} /\left((\Sigma \lambda)^{2}+\left(\Sigma 1-\lambda^{2}\right)\right]\right.$

Figure 3 presents the model. Table 6 shows that the ordinal reliability coefficient $(\omega)$ was acceptable for the latent variables (between 0.6 and 0.8 ) in the second model. The AVE for the variable "scale" was 0.6. The "innovative capacity" was from 0.2 to 0.4 , closer to the optimum of 0.5 . The second model has the discriminant capacity, stating that $\sqrt{A V E}$ of the latent variables is greater than their correlation.

In the second model, companies with more projects to innovate in the future have a higher probability of being innovative and, therefore, are more likely to adopt and disseminate 
technologies $4.0(\lambda=0.58, t=7.56)$. Regardless of perceived challenges, their capacity to innovate was $\lambda=0.2$ and $\mathrm{t}=3.99$, maintaining its importance as an explanatory variable. For the variable percentage of qualified employees, the innovative and, therefore, the diffusion capacity was $\lambda=0.2$ and $\mathrm{t}=4.03$.

Finally, the "past innovation rate" was $\lambda=0.98$, determined in a unit value to create the second model. This variable has a negative relationship with years of operation, crossing two latent variables. This relationship made it possible to improve the overall presentation of the model in the goodness of fit indices.

Among the variables that explain the "scale of operation," the total number of employees is relevant, presenting the highest factor load $(\lambda=0.92, t=5.72)$. Sales $(\lambda=0.88)$, as in the first model, were determined in a unit value to generate the corresponding calculations. Different from the first model, the variable years of operation was significant for the second model. The variable years or operation was shown to impact the scale of operation and the diffusion of technologies $4.0(\lambda=0.26, \mathrm{t}=2.8)$.

\section{DISCUSSION OF THE RESULTS}

The analysis demonstrated that both versions of the model present consistent results. Contrary to the first assumptions, the percentage of employees who hold a graduate degree and the increase in sales were not significant to influence technologies 4.0 diffusion. Regarding the increase in sales, it would be worthwhile to monitor the revenues for each specific technology - which is beyond the scope of this research.

The model suggests that companies with projects to innovate in the future can be good diffusers of technologies 4.0, corroborating the research by Horváth and Szabo (2019) and Agostini and Filippini (2019). In this sense, greater organizational flexibility, a culture of adaptation, continuous improvement practices, and new business models are elements that contribute to incorporate and disseminate technologies 4.0, as indicated by Müller et al. (2018).

Also, it was observed that each company's capacity to innovate based on a low perception of challenges is a measure of its capacity to disseminate technologies 4.0. The innovation bottlenecks can be grouped into financing problems, incentives to the economic sector, and the availability of public resources. These findings converge with the literature, as indicated by Arnold et al. (2018), Dalenogarea et al. (2018), and Ingaldi and Ulewicz (2020). The innovation challenges limit the diffusion power and explain why companies have future projects that they do not put into practice, as demonstrated in the preliminary data review.

On the other hand, this research confirms studies such as Brambilla (2018) and Horváth and Szabo (2019) about the importance of the company's size based on the total number of employees. This topic was observed in the theoretical framework presented above, demonstrating the problem faced by developing countries - and detected in the recent Encuesta TIC (ICT Survey) (Minecon, 2020) - where the size of the companies leads to differences regarding the adoption of technologies 4.0. 
Our model confirms that qualified employees contribute to increase innovation and diffusion power, corroborating the literature. Qualified human capital helps to find, understand, implement, and exploit new technologies 4.0, lowering the resistance to adoption.

In the second model, the variable years of operation was not significant as an explanatory variable, different from hypothesis H9, designed based on Ingaldi and Ulewicz (2020) and Gatica (2018). The years of operation of a company, when looking at its scale of operation, positively affects its capacity to disseminate technologies 4.0. In the long term, new business models should be born based on technologies 4.0 (Botha, 2019), changing the relationship between the companies' years of operation and diffusion power, which may confirm the hypothesis.

The literature review conducted in the Web of Science core collection in April 2021 demonstrated the absence of studies analyzing the dissemination of technologies 4.0 in Chile using structural equation modeling. Furthermore, as indicated by Kiraz et al. (2020), very few studies at a global level analyze the adoption of technologies 4.0 based on structural equations, limiting the opportunities to compare results.

In this context, the study by Rojas-Córdova et al. (2020), using data science tools through decision trees, concluded that in large Chilean companies, the most significant barriers affecting the intention to innovate are costs, lack of demand for innovations, and lack of qualified personnel. On the other hand, the barriers in the small and medium-sized Chilean companies are lack of own resources, lack of demand for innovations, and lack of information on technology. Although obtained using another methodology, these results are in line with this research when highlighting the importance of innovative trajectories and scales of operation to understand the adoption and diffusion of technologies 4.0.

\section{FINAL CONSIDERATIONS}

Chile is behind in the adoption of ICT when compared to the average of OECD countries. According to Chauhan et al. (2021), Dean and Spoehr (2018), and Mazzucato (2017), the country's first tasks are to solve the technological infrastructure problems, prepare the legal frameworks and guarantee and information security, and promote new business models and new technological markets to achieve national economic development. Likewise, the model developed in this study highlights the need to elaborate policies toward smaller companies since they face more difficulties in investing in technology. This measure would contribute to maximizing the diffusion power of the entire national market.

The Encuesta TIC (Minecon, 2020) reported that only 9\% of small and medium-sized companies in Chile have access to high-speed Internet (over $100 \mathrm{Mbps}$ ). Nhamo, Nhemachena, and Nhamo (2020) analyzed 212 countries on this matter, concluding that low ICT capacity anticipates a slow diffusion of technologies 4.0. Thus, public policies must strategically invest in ensuring a good connection speed for companies, especially smaller ones.

Equally important is to improve the educational system nationwide. The findings obtained in this study reinforce the importance of qualified employees to improve the organizations' 
capacity to adopt and disseminate technologies 4.0. In Chile, Almeida, Fernandes, and Viollaz (2020) conclude that the educational system should be reinvented to facilitate the adoption of more advanced technology. The study by Safrankova, Sikyr, and Skypalova (2020) proposes that the preparation of human capital should develop skills such as communication, problem-solving, implementation, team learning, and teamwork so that the workforce is prepared to respond to the challenges of the Fourth Industrial Revolution.

Developing countries must implement a massive training plan in digital skills for workers, including those currently employed, facilitating technology adoption and creating new companies based on technologies 4.0.

\section{Study limitations}

The limitations of this study reveal four dimensions worth addressing in future research to analyze companies' diffusion power:

- Geographic proximity. The analysis does not capture the effect of spatial proximity, which is key when promoting future clusters of 4.0 companies based on the mobility of qualified employees and the creation of new technology businesses in specific territories.

- Input-output relationships. The knowledge of the chains allows identifying the activities that are more likely to help the diffusion of technologies 4.0.

- Dynamic vision of the process. Longitudinal analysis is important to observe the dynamics of adoption, diffusion, and innovation processes around technologies 4.0 in specific territories.

- Business leadership. The literature grounded on case studies suggests that the organizational leaders' vision and commitment to adopting new technologies are relevant. Business leadership is a variable that could not be addressed in this study, but it is essential in incorporating and disseminating technologies 4.0.

\section{Note}

Research group 195212 GI/EF “Industria Inteligente y Sistemas Complejos” (smart industry and complex systems) - GISCOM - from Universidad del Bío-Bío 


\section{REFERENCES}

Agostini, L., \& Filippini, R. (2019). Organizational and managerial challenges in the path toward Industry 4.0. European Journal of Innovation Management, 22, 406-421. doi: 10.1108/EJIM-02-20180030

Almeida, R., Fernandes, M., \& Viollaz, M. (2020). Software adoption, employment composition, and the skill content of occupations in chilean firms. The Journal of Development Studies, 56(1), 169-185. doi: 10.1080/00220388.2018.1546847

Arnold, C., Veile, J., \& Voigt, K. (2018). What drives Industry 4.0 adoption? An examination of technological, organizational, and environmental determinants. International Association for Management of Technology. IAMOT 2018 Conference Proceedings. Retrieved from https://www2. aston.ac.uk/aston-business-school/documents/IAMOT2018_paper_75.pdf

Berger, R. (2016). The Industrie 4.0 transition quantified. How the fourth industrial revolution is reshuffling the economic, social and industrial model. Think Act. Ronald Berger GMBH. Munich, Germany. Retrieved from https://www.rolandberger.com/publications/publication_pdf/roland_berger_industry_40_20160609.pdf

Bogliacino, F., \& Pianta, M. (2016). The Pavitt Taxonomy, revisited: Patterns of innovation in manufacturing and service. Economía Política, 33(2), 153-180. doi: 10.2139/ssrn.2579642

Botha, A. P. (2019). Innovating for market adoption in the fourth industrial revolution. South African Journal of Industrial Engineering, 30(3), 187-198. doi: 10.7166/30-3-2238

Brambilla, I. (2018). Digital technology adoption and jobs: A model of firm heterogeneity. World Bank. Policy Research (Working Paper N. 8326). Retrieved from https://ssrn.com/abstract=3115833

Cabrera-Sanchez, J., \& Villarejo-Ramos, A. (2019). Fatores que afetam a adoção de análises de big data em empresas. RAE-Revista de Administração de Empresas, 59(6), 415-429. doi: 10.1590/s0034759020190607

Chauhan, C., Singh, A., \& Luthra, S. (2021). Barriers to industry 4.0 adoption and its performance implications: An empirical investigation of emerging economy. Joumal of Cleaner Production, 285. doi: 10.1016/j.jclepro.2020.124809

Chege, S., Wang, D., \& Suntu, S., (2020). Impact of information technology innovation on firm performance in Kenya. Information Technology for Development, 26(2), 316-345. doi: $10.1080 / 02681102.2019 .1573717$

Dalenogarea, L., Benitez, G., \& Ayala, F. (2018). The expected contribution of Industry 4.0 technologies for industrial performance. International Journal of Production Economics, 204, 383394. doi: 10.1016/j.ijpe.2018.08.019

Dean, M., \& Spoehr, J. (2018). The fourth industrial revolution and the future of manufacturing work in Australia: Challenges and opportunities. Labour \& Industry: A Journal of the Social and Economic Relations of Work, 28(3), 166-181. doi: 10.1080/10301763.2018.1502644 
Elosua, P., \& Zumbo, B. (2008). Coeficientes de fiabilidad para escalas de respuesta categórica ordenada. Psicothema, 20(4), 896-901. Retrieved from http://www.ehu.eus/gip/publicaciones/articulos/2008/1. pdf

Escobedo, M., Hernández, J., Estabané, V., \& Martínez, G. (2016, January/April). Modelos de ecuaciones estructurales: Características, fases, construcción, aplicaciones y resultados. Revista Ciencia \& Trabajo, 18(55), 16-22. doi: 10.4067/S0718-24492016000100004

Fuente, H. De la, Rojas, J., \& Leiva, V. (January, 2020). Econometric modeling of productivity and technical efficiency in the Chilean manufacturing industry. Computers and Industrial Engineering, 139, 105793. doi: 10.1016/j.cie.2019.04.006

Gatica, F. (2018). Elementos explicativos de la innovación en la industria TIC en Chile. Revista Interciencia, 43(6), 434-440. Retrieved from https://www.interciencia.net/wp-content/ uploads/2018/06/434-GATICA-43_5.pdf

Gatica, F. (2019). Innovaciones tecnológicas en las regiones de Chile: Similitudes y diferencias. Problemas del desarrollo. Revista Latinoamericana de Economía, 50(198), 87-112. doi: 10.22201/ iiec.20078951e.2019.198.67751

Gatica, F., \& Ramos, M. (2020). Políticas públicas y redes para el desarrollo delas tecnologías 4.0 en Chile. Paakat: Revista de Tecnología y Sociedad, 10(19), 1-28. doi: 10.32870/Pk.al0n19.475

Hair J., Andersen R., Tathan R., \& Black W. (1999). Análisis multivariado (5a ed.). Madrid: Prentice Hall.

Hermann, M., Pentek, T., \& Otto, B. (2016). Design Principles for Industrie 4.0 Scenarios. 49th Hawaii International Conference on System Sciences (HICSS), Koloa, HI, USA. doi: 10.1109/ HICSS.2016.488

Hooper, D., Coughlan, J., \& Mullen, M. (2008). Structural equation modelling: Guidelines for determining model fit. Electronic Journal of Business Research Methods, 6(1), 53-60. doi: 10.21427/ D7CF7R

Horváth, D., \& Szabo, R. Z. (2019). Driving forces and barriers of Industry 4.0: Do multinational and small and medium-sized companies have equal opportunities? Technological Forecasting and Social Change, 146, 119-132. doi: 10.1016/j.techfore.2019.05.021

Ingaldi, M., \& Ulewicz, R. (2020) Problems with the implementation of Industry 4.0 in enterprises from the SME sector. Sustainability, 12, 217. doi:10.3390/sul2010217

Instituto Nacional de Estadística -INE- (2018) Décima Encuesta de Innovación. Retrieved from http:// www.economia.gob.cl/2018/02/22/decima-encuesta-de-innovacion-en-empresas-2015-2016.htm

Jöreskog, K. (1994). Structural equation modeling with ordinal variables. Lecture Notes-Monograph Series, 24, 297-310. Retrieved from http://www.jstor.org/stable/4355811

Kiraz, A., Canpolat, O., Özkurt, C., \& Taşkın, H. (2020). Analysis of the factors affecting the Industry 4.0 tendency with the structural equation model and an application. Computers $\&$ Industrial Engineering, 150, 1-10. doi: 10.1016/j.cie.2020.106911 
Lasi, Heiner., Fettke, P., Feld, T, Kemper, HG., Feld Th. Hoffmann M. (2014). Industry 4.0. Business \& Information Systems Engineering. Springer 6, 239-242. doi: 10.1007/s12599-014-0334-4

Lee, J., Bagheri, B., \& Kao, H. (2015). A cyber-physical systems architecture for Industry 4.0-Based manufacturing systems. Magefacturing Letter, 3, 18-23. doi: 10.1016/j.mfglet.2014.12.001

Lepore, D., Dubbini, S., \& Micozzi, A. (February, 2021). Knowledge sharing opportunities for Industry 4.0 firms. Journal of the Knowledge Economy. 1-20 doi: 10.1007/s13132-021-00750-9

Mazzucato, M. (2017). Sistemas de innovación: Cómo dejar de subsanar las fallas de mercado para comenzar a crear mercados. In M. Cimoli, M. Castillo, G. Porcile, \& G. Stumpo (Eds.), Políticas industriales y tecnológicas en América Latina. Publicación de las Naciones Unidas-CEPAL LC/ TS.2017/91. Retrieved from https://repositorio.cepal.org/bitstream/handle/11362/42363/S1700602_ es.pdf?sequence $=4$

McDonald, R. P., \& Ho, M.-H. R. (2002). Principles and practice in reporting structural equation analyses. Psychological Methods, 7(1), 64-82. doi: 10.1037/1082-989X.7.1.64

Ministerio de Economía. (2020). Informe general de resultados: Encuesta de acceso y uso de Tecnología de Información y Comunicación (TIC) en empresas. División Política Comercial e Industrial. Unidad de Estudios. Retrieved from https://www.economia.gob.cl/wp-content/uploads/2020/07/Informe-deResultados-Encuesta-TIC.pdf

Müller, J. M., Kiel, D., \& Voigt, K.-I. (2018). What drives the implementation of Industry 4.0? The Role of Opportunities and Challenges in the Context of Sustainability. Sustainability, 10(1), 247. doi: $10.3390 / \mathrm{su} 10010247$

Nedelkoska, L., \& Quintini, G. (2018). Automation, skills use and training. OECD Social, Employment and Migration (Working Papers N. 202). Paris, France: OECD Publishing. Retrieved from https:/www.oecd-ilibrary.org/docserver/2e2f4eea-en.pdf? expires=1563986573\&id=id\&accname=gu est\&checksum=1404B9C255F4E04C3BF7D9AA0171756D

Newsom. (2018). Some clarifications and recommendations on fit indices. Psy 523/623 Structural Equation Modeling. Retrieved from http://web.pdx.edu/ newsomj/semclass/ho_fit.pdf

Nhamo, G., Nhemachena, C., \& Nhamo, S. (2020). Using ICT indicators to measure readiness of countries to implement Industry 4.0 and the SDGs. Environmental Economics and Policy Studies, 22, 315-337. doi: 10.1007/s10018-019-00259-1

Prause, M., \& Günther, C. (2019). Technology diffusion of Industry 4.0: an agent-based approach. Int. J. Computational Economics and Econometrics, 9(1/2), 29-48. doi: 10.1504/IJCEE.2019.097793

Reyes, P., Li, S., \& Visich, J. (2016). Determinants of RFID adoption stage and perceived benefits. European Journal of Operational Research, 254(3), 1. 801-812. doi: 10.1016/j.ejor.2016.03.051

Rojas-Córdova, C., Heredia-Rojas, B., \& Ramírez-Correa, P. (2020). Predicting business innovation intention based on perceived barriers: A machine learning approach. Symmetry, 12(9), 1381. doi: $10.3390 /$ sym 12091381

Safrankova, J. M., Sikyr, M., \& Skypalova, R. (2020). Innovations in workforce management: Challenges in the Fourth Industrial Revolution. Marketing and Management of Innovations, 2, 8594. doi: $10.21272 / \mathrm{mmi} .2020 .2-06$ 
Francisco Gatica-Neira

Schwab, K. (2016). La cuarta revolución industrial. Foro Económico Mundial. Barcelona, España: Editorial Debate.

Tirole, J. (2017). La economía del bien común. ¿Qué ha sido de la búsqueda del bien común? ¿En qué medida la economía puede contribuir a su realización? Madrid, España: Editorial Taurus Pensamiento.

Ventura-León, J., \& Caycho-Rodríguez, T. (2017). El coeficiente Omega: Un método alternativo para la estimación de la confiabilidad. Revista Latinoamericana de Ciencias Sociales, Niñez y Juventud, 15(1), 625-627. Retrieved from https://www.redalyc.org/pdf/773/77349627039.pdf

Viladrich, C., Angulo-Brunet, A., \& Doval, E. (2017, October). Un viaje alrededor de alfa y omega para estimar la fiabilidad de consistencia interna. Anales de Psicología, 33(3), 755-782. doi: 10.6018/ analesps.33.3.268401

Vowles, N., Thirkell, P., \& Sinha, A. (2011). Different determinants at different times: B2B adoption of a radical innovation. Journal of Business Research, 64(11), 1162-1168. doi: 10.1016/j. jbusres.2011.06.016

\section{AUTHOR'S CONTRIBUTION}

Francisco Gatica-Neira affirms that he has participated in all stages of the development of the manuscript, which includes: conceptualization and theoretical-methodological construction, theoretical review, data collection, data analysis, writing and final review. 